\title{
The United States Census Bureau
}

\section{Census of Unemployment}

During the 1930's the United States was plagued with unemployment. The National Recovery Administration had lifted the spirits of the country, but it had not created purchasing power. Congress decided that it would be necessary to measure the actual extent of unemployment complete and partial - before undertaking any step to relieve the situation. Congress appropriated $\$ 5,000,000$ and authorized the Commerce Department to set up an organization for measur ing unemployment.

In 1937 President Roosevelt appointed John D. Biggers, President of the Libbey-Owens-Ford Glass Company of Toledo, Ohio, to take charge. I was supervising a crew of silo fillers on my farm in Dutchess County when I got a telegram from Mr. Biggers, whom I had never met, asking me to meet him the next day at Hyde Park where he was going to have a talk with President Roosevelt. The result of our talk was that on the next day I was on my way back to Washington.

This campaign did not require the use of widespread local organizations such as we had used in the Liberty Loans and NRA. An arrangement 
with the Post Office Department enabled us to cover, in a two-day period, every home in the United States that had mail delivery.

Our purpose in this campaign was to show the people how to fill out the blank that was being prepared for distribution to every home that could be reached by mail. The form was designed to show full-time unemployment, partial employment, and other essential items. I had the form photographed and reproduced in practically every newspaper in the United States and made a motion picture film, which was run in 5,000 theaters, in which actors went through the process of filling out this chart. By the time the distribution was made by the Post Office Department, we had used every possible device of publicity.

In those days President Roosevelt occasionally gave 15-minute "Fireside Chats" over the radio. I asked the White House to devote one of these broadcasts to the Census of Unemployment. Steve Early told me to write the manuscript and submit it. The only change the President made was the addition of a line or two to fit timing necessities. Prior to this speech I had prepared a shorter version for the President to record for radio. Steve Early invited me over to watch the recording. The President came down to the recording room in his wheelchair and remained in it while he read the manuscript and recorded. It happened to be one of the days when he was not 
as cheerful as he was ordinarily. I can recall a pleasanter occasion when he was in the highest of good humor.

Up at my farm in Dutchess County, Lowell Thomas had telephoned that his baseball team was going over to Hyde Park that Sunday afternoon to play a ball game against the Washington newspaper correspondents' team. It was an an nual event. Bert St. Clair, who had been associated with me in the Liberty Loan Campaign and in the NRA, and who was then employed in New York City, had driven to our farm that day and together we went to see the ball game. The President's car was parked near third base, and we were in conversation with the President who was sitting in the rear seat watching the game and having the time of his life. He was kidding the players for their successes and fumbles. Before the game was over it was necessary for St. Clair to leave and go to New York, and the President chided us for leaving "before they put the keg of beer on third base."

The Census of Unemployment was one of the snappiest and most successful of all government campaigns. In two consecutive days the Post Of fice delivered more than $36,000,000$ of these blanks to American homes, and the result was amazing. The returns showed that nearly 7,000,000 were without any job, and 5,000,000 more had varying degrees of employment. One of the 
rare cases in government was Mr. Biggers's termination of this enterprise with a report to Congress that he was turning back $\$ 2,500,000$ of the $\$ 5,000,000$ that Congress had appropriated. I know of no other instance of this kind in government history.

\section{In the Census Buteau}

During the 1937 Census of Unemployment we got a great deal of cooperation from the Bureau of the Census and made use of its vast quantity of basic statistics. In 1939 I was asked by the Census Bureau to handle their public relations problems, just prior to the 1940 census. I continued with the Census Bureau until 1952 - two years beyond the retirement age of 70 . (A federal employee is permitted an extension of two years only upon approval from the President.) My thirteen years with the greatest statistical organization in the world proved to be one of the most interesting and rewarding of my life.

The Census Bureau is one of the oldest agencies of government. It was set up in the Constitution to determine representation in Congress for each state according to its population. As the nation expanded, the duties of the Bureau went far beyond that of counting the population. Regular surveys of industry, agriculture, trade, trans portation, employment, housing, and many other areas of national life gradually came to be part 
of the Bureau's activities. People in a variety of fields, professional and business, turned to the Census Bureau for information.

It is doubtful if there is a more interesting and solid public relations opportunity in the world than that associated with the preparation for a decennial census of population. A nationwide operation brings the Census Bureau in contact with at least one person of every family in the United States. Preliminary publicity is calculated to make the enumerator a welcome figure at each door and to avoid unpleasant incidents. Emphasis is put on the purposes of the census: the national value of the results, the need for accuracy in the replies, and familiarity with the questions to be asked.

Just prior to the 1940 census, I prepared a letter for the director of the Bureau inviting publishers of large daily newspapers to send advertising representatives to Washington for a twoday conference when the 1940 census material became available. More than two hundred newspapers were represented at the meeting. The organization of Newspaper Promotion Managers has now expanded to nearly 500 , and it holds national and regional meetings annually. When my Census Bureau associates gave me a luncheon at the time of my retirement a representative of the Newspaper Promotion Managers presented me with a life membership.

For the 1950 census preliminary material ap- 
peared in 19,000 newspapers and 2,000 periodicals, was heard and seen over 1,900 radio and television stations and in thousands of motion picture theaters. All these agencies of public education find a decennial census attractive as news because it concerns every family in the nation. American industry always supports a census because it affords them with essential information on population movements as a basis for advertising and the allocation of production.

We spent less than $\$ 150,000$ on publicity for the 1950 census, and more than half of that was the cost of booklets for school children who could help their mothers answer the questions of an enumerator. Following the 1950 census the Department of Commerce awarded a gold medal to me for outstanding achievement. It was presented by Secretary of Commerce Charles Sawyer in the auditorium of the Department of Com merce.

\section{Iowa in the Census}

In the census of 1840 Iowa had 43,112 people and that included that part of Minnesota lying west of the Mississippi and a line drawn from its source northward to Canada. In the census of 1850 , four years after the state was admitted to the Union, Iowa had 192,214; 2,231,853 in 1900 , and 2,621,073 in 1950 .

If any proof is needed that Iowa is the number 
UNITED STATES CENSUS BUREAU 341

one state in agriculture the Census Bureau can provide it. The 1954 census demonstrated that agricultural efficiency reached its peak in Iowa. The census found 192,933 farms in Iowa, of which 178,248 were commercial farms and the balance residential farms with litttle production. The av erage size of Iowa farms in 1954 was 176.5 acres compared with 169.7 acres four years earlier. The state has 94 per cent of its land in farms. The Iowa farm labor force consisted of 181,916 operators; only 48,022 hired workers and 110,625 unpaid family workers - a total farm labor force of 340,563 or only about 1.7 workers per farm. This total is about 200,000 fewer workers than General Motors employs throughout the United States; vastly fewer than the employees of American Telephone and Telegraph and only a little more than the employees of United States Steel.

Increased mechanization enabled Iowa farmers to reduce their cost of hired labor from $68.3 \mathrm{mil}$ lion dollars in 1949 to 53 million dollars in 1954. In the same period Iowa farmers increased their expenditures for gasoline and oil from $75.6 \mathrm{mil}$ lion to 84.3 million. And by owning more ma chinery they decreased their cost of machine hire from 37.3 million dollars to 31.7 million dollars. Iowa, heretofore a small user of fertilizer, reported the purchase of $\$ 50,000,000$ worth of fertilizer and lime.

With approximately two tractors per farm 
Iowa's 340,563 farm workers harvested 530,000,000 bushels of corn from 9.7 million acres; 222,000,000 bushels of oats, and 55.6 million bushels of soybeans making Iowa, for the first time, the leading state in soybean production. Among a long list of additional products Iowa took the championship in popcorn production $-40,000,000$ pounds - surely enough to make most of the motion picture theaters of the nation uninhabitable for weeks.

In 1954 Iowa farmers marketed 2,657,011 cattle, mostly fat steers, and received $\$ 486,000,000$ for them; $14,001,563$ hogs yielding $\$ 510,801,813$; sheep sales amounting to over $\$ 23,000,000$, and horse and mule sales of only $\$ 870,832$. The last census found that there were only 96,584 horses left on Iowa farms or only one-half a horse per farm. For many years, Iowa has been the champion producer of eggs, and in 1954 it amounted to 238 million dozen, enough eggs to supply six dozen for every family in the United States.

In 1950 Iowa had 10,317 farms that sold products for $\$ 25,000$ or more each; 52,134 that sold from $\$ 10,000$ to $\$ 25,000$, and 59,884 with sales between $\$ 5,000$ and $\$ 10,000$.

Iowa's gross product sales in 1954 exceeded 1.8 billion dollars. Texas with five times the land area of Iowa sold a little over one billion. South Dakota's gross sales were 436 million dollars; Kansas, 802 million; Nebraska, 882 million; Min- 
nesota, 984 million, and Illinois, \$1,500,000,000.

The asset value of Iowa farms - land and buildings only - in 1954 passed 7 billion dollars. Adding the value of livestock, crops on hand, and machinery, the gross farm values in the state would vastly exceed 10 billion dollars. The mortgage debt in 1950, four years earlier, was only 433 million dollars, and the Iowa farms supporting this indebtedness represented a value of 1.8 billion dollars. The value of all of the stock of American Telephone and Telegraph holdings in the United States is about 15 billion dollars. The working capital engaged in Iowa agriculture greatly exceeds the combined net working capital of American Telephone and Telegraph, General Motors, and United States Steel. Business concerns can turn their capital over many times a year, while the farmer is limited by the season.

Between 1950 and 1954 Iowa lost 10,226 farms by merger; lost 220,000 acres of farmland through industrial expansion and otherwise; increased its average size of farms by 8.2 acres, and showed an increased value for land and buildings of $\$ 8500$ per farm.

Loafing away my retirement days at the round table at the National Press Club in Washington and listening to the transient wisdom from correspondents who come and go, I often think of an other promotion that should be undertaken by someone. It would be designed to stop the migra- 
tion of young people out of Iowa. For many years Iowa has been giving her sons and daughters to the rest of the nation at an alarming rate. In the 1950 census $3,230,275$ reported that they were born in Iowa. Of these only 2,039,135 were living in Iowa in 1950, and 1,191,140 were living in other states.

Between 1940 and 1950 Iowa had a net gain in population of 84,000 . In that decade there were 544,061 births and 259,000 deaths. The net outmigration in the ten years was 176,000 .

If it costs $\$ 15,000$ to bring up a child, it would seem that Iowa is making a contribution to other states of $\$ 2.6$ billion in 10 years. Can Iowa, even with its great capacity for production, afford such a gift to other states? It would seem that such an amount of money might better be used to bring new industries to Iowa, especially at this time when there is great mobility in industry.

FRANK R. WILSON 